\title{
Evaluation of feeding Indigofera zollingeriana leaf meal and Sardinella lemuru fish oil on lipids metabolism of local ducks
}

\author{
N.M.J. Arini, Sumiati and R. Mutia \\ Faculty of Animal Science, Bogor Agricultural University \\ Jl. Agatis, Darmaga Campus, Bogor 16680 - Indonesia \\ CorrespondingE-mail :y_sumiati@yahoo.com
}

Received September 10, 2016; Accepted January 30, 2017

\begin{abstract}
ABSTRAK
Penelitian bertujuan untuk mengevaluasi efektivitas penggunaan tepung daun Indigofera zollingeriana (I) dan minyak ikan Sardinella lemuru (L) terhadap penurunan kadar kolesterol dan metabolisme lipida itik petelur. Penelitian ini menggunakan 144 itik Magelang, umur 20-32 minggu, periode layer dengan rataan bobot badan $1.72 \pm 0.12 \mathrm{~kg}$, yang dibagi menjadi 6 kelompok perlakuan pakan, 3 ulangan, dan masing-masing 8 ekor. Rancangan penelitian menggunakan Rancangan Acak Lengkap Faktorial $3 \times 2$, dengan faktor pertama penggunaan tepung daun Indigofera zollingeriana sebagai pengganti tepung bungkil kedelai $(0 \%, 5.5 \%, 11 \%)$. Faktor kedua merupakan penggunakan minyak ikan Sardinella lemuru (0\%, 2\%). Hasil menunjukkan bahwa perlakuan I5.5L2 berpengaruh sangat nyata $(\mathrm{P}<0,01)$ terhadap trigliserida, HDL, dan LDL. Perlakuan I0L2 berpengaruh nyata $(\mathrm{P}<0,05)$ menurunkan kolesterol total pada profil lipida darah dan kolesterol daging. Perlakuan I11L2 berpengaruh sangat nyata $(\mathrm{P}<0,01)$ menurunkan kolesterol telur. Kesimpulan dari penelitian ini adalah dengan pemberian tepung daun Indigofera zollingeriana dan minyak ikan lemuru $2 \%$ dalam ransum dapat menjaga keseimbangan profil lipida darah dengan menurunkan trigliserida, LDL, kolesterol, dan meningkatkan HDL pada plasma itik petelur dan berperan penting dalam metabolime lipida itik petelur Magelang dalam menghasikan telur dan daging dengan kandungan kolesterol yang rendah.
\end{abstract}

Kata-kata kunci: Indigofera zollingeriana, itik Magelang, kolesterol, minyak ikan Sardinella lemuru

\section{ABSTRACT}

The objective of this study was to evaluate the effectiveness usage of Indigofera zollingeriana leaf meal (I) and Sardinella lemuru fish oil (L) in diets on the decreasing levels of cholesterol and lipid metabolism of laying duck. One hundred and forty-four Magelang ducks aged 20-32 weeks, laying periode, with an average body weigth of $1,72 \pm 0,12 \mathrm{~kg}$ were used, which were divided into 6 groups of experimental diets, 3 replications, and of 8 layers each. A completely randomized design, $3 \times 2$ factorial design was used in this experiment. The first factor was usage Indigofera zollingeriana leaf meal which replaced protein soybean meal $(0 \%, 5,5 \%, 11 \%)$. The second factor was usage Sardinella lemuru fish oil $(0 \%, 2 \%)$. The results showed that the treatment (I5.5L2) was highly significant affected $(\mathrm{P}<0.01)$ the level of triglyceride, HDL, and LDL in the blood. The treatment I0L2 significantly decrease $(\mathrm{P}<0.05)$ total cholesterol of blood lipid profile and meat cholesterol. The treatment (I11L2) was highly significantly decreased $(\mathrm{P}<0.01)$ egg cholesterol. The conclusion of this study was that feeding Indigofera zollingeriana leaf meal 5.5\% and Sardinella lemuru fish oil $2 \%$ in laying duck's diet could maintain the balance of blood lipid profiles by lowering plasma triglycerides, LDL, cholesterol and raising up plasma HDL and plays an important role on lipid metabolism of Magelang laying ducks to produce eggs and meat with low cholesterol content.

Keywords : cholesterol, Indigofera zollingeriana, Sardinella lemuru fish oil, Magelang duck 


\section{INTRODUCTION}

Eggs contain a balanced amino acids, essential fatty acids, some minerals and vitamins (McNamara and Thesmar, 2005). Duck is one of the birds that produce eggs with higher nutritional value. The nutrient content of eggs, among others: water $73.7 \%, 12.9 \%$ protein, $11.2 \%$ fat, $0.9 \%$ carbohydrate and fat was not exist in egg white (Komala, 2008). Cholesterol content at $17 \mathrm{mg} / \mathrm{g}$ of duck egg yolk was higher than $14 \mathrm{mg} / \mathrm{g}$ yolk in chicken eggs (Chang and Huang, 2001). Cholesterol is needed by the human body to form cell membranes, producing sex hormones and the formation of bile acids needed on fat digestion. High cholesterol in eggs is not good if consumed by someone who is sensitive to cholesterol

Sardinella lemuru fish oil is one of the sources of unsaturated fatty acids. Fish oil is naturally rich in omega-3 fatty acids such as eicosapentaenoic acid (EPA) and docosahexaenoic acid (DHA) (Trujillo et al., 2016). According to Atakisi et al. (2009), eicosapentaenoic acid (EPA) and docosahexaenoic acid (DHA) is more effective in lowering cholesterol compared with alpha-linoleic acid (ALA). Eggs enriched with omega-3 fatty acids through dietary fish oil supplementation may reduced the stability of lipid oxidation in fresh eggs (Botsoglou et al., 2012). The weakness of omega-3 fatty acids are susceptible to lipid oxidation which has a negative impact on the nutritional value, flavor, color and texture of the food (Avila-Ramos et al., 2013). The use of antioxidants was essential to prevented the oxidation of lipids in animal products (Kong et al., 2010). One of the materials that could be used to protect omega-3 fatty acids from oxidation was Indigofera zollingeriana leaf meal that contained beta-carotene.

The objectives of this study was to evaluate the effectiveness of the use of Indigofera zollingeriana leaf meal and Sardinella lemuru fish oil on the decreased levels of cholesterol and lipid metabolism in laying ducks.

\section{MATERIALS AND METHODS}

\section{Animals and Experimental Diets}

A total of 144 laying ducks, 20 weeks of age, with an average body weigh of $1.72 \pm 0.12 \mathrm{~kg}$ were put in litter cages $(2 \times 1.25 \mathrm{~m})$. Each cage was filled up by 8 ducks and grouped by treatments at the Poultry Research Unit, Department of
Nutrition and Feed Technology, Faculty of Animal Science, Bogor Agricultural University. Laying ducks were raised in litter cages with room temperature and the light-dark cycle was set at 12 $\mathrm{h}$ each.

\section{Indigofera zollingeriana Leaf Meal Preparation.}

Harvesting Indigofera zollingeriana leaves aged 60 days defoliation was used by taking the third leaf from the leaves of shoots up to 20 leaves. The leaf were dried in the greenhouse until half dry so as not to cause discoloration of the green colour then continued dried using an oven on $60^{\circ} \mathrm{C}$ for 24 hours. Indigofera zollingeriana leaf meal was ready to produce.

\section{Procedure}

Laying ducks were divided into 6 groups, each treatment was subjected to three replications. The layers were given $120 \mathrm{~g}$ of feed per bird per day which fed in the (morning and afternoon). Drinking water was given ad libitum. The ducks were adjusted pre-experimentally, by feeding them a commercial diet on week 20 to 21 . Between week 21 to 32, were fed a dietary treatment. Experimental data were recorded between week 22 and 32 (a total of 11 weeks). Eggs were collected two times daily (morning and afternoon) and weighed daily. Composition and nutrient content used in this study is presented in Table 1.

\section{Rations}

The diets were formulated according to Leeson and Summers (2005). The first ingredient is mixed with yellow corn, palm oil, soybean meal, fish meal, Sardinella lemuru fish oil. The second ingredient is mixed with Indigofera zollingeriana leaf meal, rice bran, $\mathrm{CaCO} 3$ (calcium carbonate), premix and DL-methionine. The entire material then stirred until homogeneous in a mixing machine (mixer).

\section{Data Collection}

On week 32, three ducks were randomly choosen from each replication. Blood sample collection was carried out on the 3 ducks gathered (total 18). Blood was taken from pectoralis vena by $3 \mathrm{ml}$ syringe and then was placed in the sample tube. Blood sample was placed in Styrofoam box containing ice cubes and transported to the laboratory. In the laboratory, blood sample was placed in $4^{\circ} \mathrm{C}$ refrigerator for 12 hours before it 
Table 1. Composition and Nutrient Content of Experimental Diet

\begin{tabular}{lcccccc}
\hline Feed Ingredient (\%) & I0L0 & I5.5L0 & I11L0 & I0L2 & I5.5L2 & I11L2 \\
\hline Corn & 57.1 & 53.4 & 49.7 & 49.7 & 45.8 & 42.2 \\
Rice bran & 7.8 & 10.9 & 14 & 13 & 16.3 & 19.1 \\
Soybean meal & 20 & 15 & 10 & 20 & 15 & 10 \\
Indigofera zollingeriana & 0 & 5.5 & 11 & 0 & 5.5 & 11 \\
Fish meal & 5.4 & 5.5 & 5.6 & 5.6 & 5.8 & 6 \\
Palm oil & 2 & 2 & 2 & 2 & 2 & 2 \\
Lemuru fish oil & 0 & 0 & 0 & 2 & 2 & 2 \\
CaCO3 & 6.9 & 6.9 & 6.9 & 6.9 & 6.8 & 6.9 \\
NaCl & 0.2 & 0.2 & 0.2 & 0.2 & 0.2 & 0.2 \\
Premix ${ }^{1}$ & 0.5 & 0.5 & 0.5 & 0.5 & 0.5 & 0.5 \\
DL-Methionin & 0.1 & 0.1 & 0.1 & 0.1 & 0.1 & 0.1 \\
Total & 100 & 100 & 100 & 100 & 100 & 100 \\
Calculated nutrient content (\%) & & & & & & \\
GE (kkal/kg) & 4171 & 3996 & 3945 & 4053 & 3801 & 4060 \\
Dry matter & 84.34 & 91.28 & 91.95 & 87 & 87.95 & 90.05 \\
Crude protein & 16.32 & 16.36 & 15.75 & 15.72 & 15.59 & 15.69 \\
Ash & 8.13 & 8.28 & 9.4 & 9.06 & 9.78 & 9.69 \\
Crude fat & 4.59 & 4.79 & 5.15 & 6.86 & 3.66 & 6.45 \\
Crude fiber & 5.76 & 5.9 & 6.44 & 5.19 & 6.26 & 6.48 \\
Calcium & 4.17 & 3.63 & 3.92 & 3.79 & 3.87 & 3.68 \\
Total phosphorus & 0.55 & 0.55 & 0.51 & 0.53 & 0.61 & 0.67 \\
\hline
\end{tabular}

IOL0 : feed without Indigofera zollingeriana leaf meal and lemuru fish oil, I5.5L0 : feed plus 5.5\% Indigofera zollingeriana leaf meal without lemuru fish oil, I11L0 : feed plus $11 \%$ Indigofera zollingeriana leaf meal without lemuru fish oil, I2L0 : feed without Indigofera zollingeriana leaf meal plus $2 \%$ lemuru fish oil, I5.5L2 : feed plus 5.5\% Indigofera zollingeriana leaf meal and $2 \%$ lemuru fish oil, and I11L2 : feed plus $11 \%$ Indigofera zollingeriana leaf meal and $2 \%$ lemuru fish oil. ${ }^{1}$ Premix composed of the following: vitamin A 12,000,000 IU, vitamin D3 2,000,000 IU, vitamin E 8,000 IU, vitamin K 2 g, vitamin $\mathrm{B}_{1} 2 \mathrm{~g}$, vitamin $\mathrm{B}_{2} 5$ $\mathrm{g}$, vitamin $\mathrm{B}_{6} 0.5 \mathrm{~g}$, vitamin $\mathrm{B}_{12} 0.012 \mathrm{~g}$, vitamin C $25 \mathrm{~g}$, calcium D-panthothenate $6 \mathrm{~g}$, niacin $40 \mathrm{~g}$, cholin chloride $10 \mathrm{~g}$, methionin $30 \mathrm{~g}$, lysine $30 \mathrm{~g}$, manganese $120 \mathrm{~g}$, iron $20 \mathrm{~g}$, iodine $0.2 \mathrm{~g}$, zinc $100 \mathrm{~g}$, cobalt $0.2 \mathrm{~g}$, copper $4 \mathrm{~g}$, zinc bacitracin $21 \mathrm{~g}$, excipient $10 \mathrm{~g}$ q.s.

was centrifuged by $3500 \mathrm{rpm}$ for 10 minutes. Supernatant in the form of plasma was taken using sterile pipette and placed in eppendorf tube for further analysis.

\section{Parameters Observed}

The lipid profile of blood plasma consisted of triglyseride, total cholesterol (TC), Low Density Lipoprotein (LDL), High Density Lipoprotein (HDL) using CHOD-PP method, and the cholesterol content of egg yolk and meat were analyzed using Liberman Burchard method (Burke et al., 1974).

\section{Data Analysis}

Data obtained were tabulated using excel and analyzed using Completely Random Design (CRD). If there was significant or very significant effect of treatments, then followed by Duncan's Multiple Range Test (Steel and Torrie, 1984). 


\section{RESULTS AND DISCUSSION}

Effect Indigofera zollingeriana leaf meal and Sardinella lemuru fish oil to lipid profile of blood plasma was presented in Table 2. Plasma triglyseride levels were significantly $(\mathrm{P}<0.01)$ decreased after Indigofera zollingeriana leaf meal and Sardinella lemuru fish oil administration for eleven weeks in experimental animals compared to control (IOL0) (Table 2). I11L2 was not different $(\mathrm{P}>0.01)$ from $\mathrm{I} 5.5 \mathrm{~L} 0$ and $\mathrm{I} 5.5 \mathrm{~L} 2$. Furthermore I0L0, I11L0 and IOL2 was not different from I5.5L0 and I5.5L2, but I11L2 was different from IOL0, I11L0 and IOL2. Plasma triglyseride of laying duck in this research ranged from 233.77 to $429.80 \mathrm{mg} / \mathrm{dl}$. This study showed that inclusion of Indigofera zollingeriana leaf meal and Sardinella lemuru fish oil in the diet significantly reduced triglyseride levels in laying ducks (Table 2). According to Schreiber et al. (2013) beta carotene is a potent natural antioxidants. Beta carotene is an antioxidant will gobble free radicals that lead to increased activity of the enzyme lipoprotein lipase. The enzyme lipoprotein lipase activated by apolipoprotein $\mathrm{C}$, serves to hydrolyze triglycerides into fatty acids and glycerol. The more triglycerides are hydrolyzed causing a decrease in plasma triglycerides. Antioxidants from beta carotene also serves to protect the omega-3 fatty acids. Omega3 fatty acid comprising $60 \%$ long chain fatty acids omega-3 EPA and DHA are susceptible to lipid oxidation. According to Dalle Zotte et al. (2006), omega-3 fatty acids play a role in lowering plasma triglycerides. Omega-3 fatty acids of Sardinella lemuru fish oil may inhibit Diacyl glycerol transferase enzyme (DGAT) and Phosphatidic Acid Phosphohydrolase enzyme (PAP) that will reduce the availability of fatty acids for the synthesis of triglycerides. Inhibition of the synthesis of triglycerides will lead to the decreased of plasma triglycerides.

The results showed that group IOL2 had a significantly $(\mathrm{P}<0.05)$ lower plasma TC levels of $129.10 \pm 14.97 \mathrm{mg} / \mathrm{dl}$, followed by group IOL0 with $133.33 \pm 17.55 \mathrm{mg} / \mathrm{dl}$ plasma TC levels. Based on result administration of Indigofera zollingeriana leaf meal and Sardinella lemuru fish oil reduced TC levels significantly (Table 2). This study showed that the addition of lemuru fish oil in the ration provide a good influence on the content of plasma cholesterol in laying ducks. According to Dalle Zotte et al. (2006) omega-3 fatty acids play a role in lowering cholesterol levels. When cholesterol is transported from the intestine peripherals to the liver, omega- 3 fatty acids will inhibit HMG-CoA reductase which served to transform asetoasetil CoA into mevalonate (Babio et al,. 2010). This causes the synthesis of endogenous cholesterol becomes blocked. Antioxidants also play a role in lipid metabolism, especially cholesterol. The antioxidant activity of carotenoids based conjugated system of the electron-rich chain polyenes, and responsible for meeting the singlet oxygen and free radicals to terminate the chain reaction that is adverse (McNulty et al., 2008). Antioxidants prevent the formation of free radicals in the liver for the synthesis of endogenous cholesterol. Products of cholesterol by the liver is reduced which will result in a decrease in serum cholesterol levels. Several studies have shown that EPA and DHA more effectively lower plasma cholesterol compared with ALA (Atakisi et al., 2009). Chan et al. (2003) reported that omega-3 fatty acids may reduce the rate of entry of VLDL particles into the blood circulation which will be converted into LDL particles.

Indigofera zollingeriana leaf meal and Sardinella lemuru fish oil had significant $(\mathrm{P}<0.01)$ reduction in plasma LDL-C levels in laying ducks. The lowest plasma LDL-C levels was shown on group I0L2 $(37.38 \pm 3.22 \mathrm{mg} / \mathrm{dl})$. Group I5.5L0 had significantly $(\mathrm{P}<0.01)$ higher mean plasma LDL-C levels of $86.75 \mathrm{mg} / \mathrm{dl}$. I0L2 which was not different $(\mathrm{P}>0.01)$ from $\mathrm{I} 5.5 \mathrm{~L} 2$ and I11L2. Furthermore, I5.5L0 was not different from I11L0, but I5.5L0 was different from I0L2. LDL plasma of laying duck in this research ranged from 37.38 to $86.75 \mathrm{mg} / \mathrm{dl}$. In this research Indigofera zollingeriana leaf meal and Sardinella lemuru fish oil supplementation significantly reduces plasma levels of LDL after eleven weeks of treatment in the diet of laying ducks. Low levels of plasma LDL is usually followed by low levels of triglycerides in plasma. The rest of the hydrolysis of the triglycerides will be metabolized in the liver which will become LDL. Yang et al. (2010) reported that the long-chain fatty acids omega-3 (EPA and DHA) affected to the decreased secretion of LDL from the liver. LDL are lipoproteins that are rich in cholesterol because it transports much cholesterol in the blood. Decrease of LDL level is suspected because of the omega-3 fatty acid can reduce the production and secretion of VLDL particles are activated by Apolipoprotein B. Omega-3 fatty 
Table 2. Lipid Profile of Blood Plasma of Laying Duck Supplemented by Indigofera zollingeriana Leaf Meal and Lemuru Fish Oil

\begin{tabular}{lcccc}
\hline \multirow{2}{*}{ Parameter } & Lemuru Fish & \multicolumn{3}{c}{ Indigofera zollingeriana Leaf Meal } \\
\cline { 3 - 5 } & Oil & I0 & I5.5 & I11 \\
\hline Triglyseride & L0 & $311.26 \pm 44.22^{\mathrm{B}}$ & $331.46 \pm 14.24^{\mathrm{AB}}$ & $233.77 \pm 27.81^{\mathrm{B}}$ \\
$(\mathrm{mg} / \mathrm{dl})$ & L2 & $297.85 \pm 29.64^{\mathrm{B}}$ & $329.47 \pm 63.91^{\mathrm{AB}}$ & $429.80 \pm 60.26^{\mathrm{A}}$ \\
Total cholesterol & L0 & $133.33 \pm 17.55^{\mathrm{c}}$ & $173.45 \pm 6.21^{\mathrm{a}}$ & $140.68 \pm 14.12^{\mathrm{bc}}$ \\
$(\mathrm{mg} / \mathrm{dl})$ & L2 & $129.10 \pm 14.97^{\mathrm{c}}$ & $146.52 \pm 13.40^{\mathrm{abc}}$ & $164.97 \pm 23.16^{\mathrm{ab}}$ \\
LDL & L0 & $59.93 \pm 8.68^{\mathrm{BC}}$ & $86.75 \pm 6.11^{\mathrm{A}}$ & $75.64 \pm 10.55^{\mathrm{AB}}$ \\
$(\mathrm{mg} / \mathrm{dl})$ & L2 & $37.38 \pm 3.22^{\mathrm{D}}$ & $44.19 \pm 4.12^{\mathrm{CD}}$ & $45.06 \pm 1.32^{\mathrm{CD}}$ \\
$\mathrm{HDL}$ & L0 & $26.26 \pm 2.45^{\mathrm{B}}$ & $20.41 \pm 3.16^{\mathrm{B}}$ & $18.29 \pm 2.33^{\mathrm{B}}$ \\
$(\mathrm{mg} / \mathrm{dl})$ & L2 & $24.67 \pm 2.58^{\mathrm{B}}$ & $39.43 \pm 6.35^{\mathrm{A}}$ & $24.16 \pm 3.58^{\mathrm{B}}$
\end{tabular}

IOL0 : feed without Indigofera zollingeriana leaf meal and lemuru fish oil, I5.5L0 : feed plus 5.5\% Indigofera zollingeriana leaf meal without lemuru fish oil, I11L0 : feed plus $11 \%$ Indigofera zollingeriana leaf meal without lemuru fish oil, I2L0 : feed without Indigofera zollingeriana leaf meal plus $2 \%$ lemuru fish oil, I5.5L2 : feed plus 5.5\% Indigofera zollingeriana leaf meal and 2\% lemuru fish oil, and I11L2 : feed plus $11 \%$ Indigofera zollingeriana leaf meal and $2 \%$ lemuru fish oil. Significant difference between various groups is by Duncan's Mutiple Range Test, ${ }^{\text {abcd }} \mathrm{P}<0.05,{ }^{\mathrm{ABCD}} \mathrm{P}<0.01$.

acid inhibits Diacyl glycerol transferase enzyme (DGAT) and Phosphatidic Acid Phosphohydrolase enzyme (PAP) so as to reduce the secretion of VLDL which will affect the reduction in LDL. According to Bruss (2008) that the inhibition of HMG-CoA reductase inhibitors cause a decrease in cholesterol synthesis and increase the number of LDL receptors located in the liver cell membrane and extra hepatic tissues, so that the levels of total cholesterol and LDL in plasma decline.

Plasma HDL-C levels were significantly increased $(\mathrm{P}<0.01)$ with I5.5L2 administration in laying ducks compared with all other treatments (Table 2); however, I0L0, I5.5L0, I11L0, I0L2, and I11L2 were not different. This study showed that the combination of Indigofera zollingeriana leaf meal and Sardinella lemuru fish oil significantly increased plasma HDL levels (Table 2). Plasma HDL of laying duck in this research was 18.29 to $39.43 \mathrm{mg} / \mathrm{dl}$. When combined with Indigofera zollingeriana leaf meal, the ability of omega-3 fatty acid from Sardinella lemuru fish oil in lowering LDL and raising up HDL were more potent. The mechanism of the increase in plasma HDL levels might be due to lipoprotein lipase enzyme activity of Sardinella lemuru fish oil. Another possible mechanism was the active compounds of beta-carotene of Indigofera zollingeriana leaf meal whick acted as a potential as an antioxidant that increased the secretion of bile acids (Carvajal-zarrabal et al., 2005). Beta carotene increased the incorporation of esterification of cholesterol in HDL-C to be transported to the liver (Carvajal- zarrabal et al., 2005). Cholesterol in the liver to be converted into folic acid and kenokolat acid that are secreted into the bile as bile acids (Murray et al., 2009). Bile acids are stored in the gallbladder and are secreted into the small intestine to aid in the digestion of fat in the diet. This causes the total cholesterol level in the blood decreases which leads to increased plasma HDL levels. According to Adkins and Kelley (2010), omega-3 fatty acids can also inhibit the secretion of low density lipoprotein (LDL) in the liver, which would affect the levels of plasma high density lipoprotein (HDL)

Table 3 showed that feed supplemented with Indigofera zollingeriana leaf meal and Sardinella lemuru fish oil significantly affected $(\mathrm{P}<0.01)$ egg cholesterol of 32 weeks old laying duck. I11L2 
Table 3. Cholesterol of Eggs and Meat of Laying Duck Supplemented by Indigofera zollingeriana Leaf Meal and Lemuru Fish Oil

\begin{tabular}{ccccc}
\hline \multirow{2}{*}{ Parameter } & Lemuru Fish & \multicolumn{3}{c}{ Indigofera zollingeriana Leaf Meal } \\
\cline { 3 - 5 } & Oil & I0 & I5.5 & I11 \\
\hline Egg cholesterol (mg/g) & L0 & $8.46 \pm 0.36^{\mathrm{BC}}$ & $7.83 \pm 0.17^{\mathrm{BC}}$ & $8.44 \pm 0.43^{\mathrm{BC}}$ \\
& L2 & $8.85 \pm 0.68^{\mathrm{AB}}$ & $9.58 \pm 0.48^{\mathrm{A}}$ & $7.66 \pm 0.26^{\mathrm{C}}$ \\
Meat cholesterol (mg/g) & L0 & $0.28 \pm 0.01^{\mathrm{a}}$ & $0.12 \pm 0.01^{\mathrm{b}}$ & \\
& L2 & $0.11 \pm 0.01^{\mathrm{b}}$ & $0.14 \pm 0.01^{\mathrm{b}}$ & \\
\hline
\end{tabular}

I0L0 : feed without Indigofera zollingeriana leaf meal and lemuru fish oil, I5.5L0 : feed plus 5.5\% Indigofera zollingeriana leaf meal without lemuru fish oil, I11L0 : feed plus $11 \%$ Indigofera zollingeriana leaf meal without lemuru fish oil, I2L0 : feed without Indigofera zollingeriana leaf meal plus $2 \%$ lemuru fish oil, I5.5L2 : feed plus 5.5\% Indigofera zollingeriana leaf meal and 2\% lemuru fish oil, and I11L2 : feed plus $11 \%$ Indigofera zollingeriana leaf meal and $2 \%$ lemuru fish oil. Significant difference between various groups is by Duncan's Mutiple Range Test, ${ }^{\text {abcd }} \mathrm{P}<0.05,{ }^{\mathrm{ABCD}} \mathrm{P}<0.01$.

was not different $(\mathrm{P}<0.05)$ from I0L0, I5.5L0, I11L0. I5.5L2 was not different from I0L2. I11L2 was different from I0L2 and I5.5L2. The effect of Indigofera zollingeriana leaf meal and Sardinella lemuru fish oil in diet produce eggs cholesterol levels ranged 7.66 to $9.58 \mathrm{mg} / \mathrm{g}$ are relatively similar to 7.29 to $9.65 \mathrm{mg} / \mathrm{g}$ of laying duck by Darmawan (2013). Decreased plasma cholesterol levels will affect the reduction in cholesterol levels in animal products, especially eggs. Results Palupi et al. (2014) showed that the use of Indigofera zollingeriana leaf meal could be used up to $15.6 \%$ in the diet of laying hens in the equivalent of replacing the use of $45 \%$ soybean meal, resulting on lowering cholesterol egg yolk cholesterol by $54.13 \%$. The cholesterol functioned in poultry as forming materials of vitelogenin, streroid hormone and structural constituent of cells. Combinations of Indigofera zollingeriana leaf meal and Sardinella lemuru fish oil interact well. The high percentage of Indigofera zollingeriana leaf meal replace up to $11 \%$ protein soybean meal can increase the content of betacarotene in the diet of laying ducks. Carotenoids (beta carotene) provide antioxidant defenses in lipids (Surai et al., 2016). Moreover, the Sardinella lemuru fish oil rich in omega-3 fatty acids that most have double bonds so susceptible to oxidative degradation (Shahidi and Zhang, 2010). According to Levi et al. (2009) cholesterol is a steroid hormone precursor that will trigger the hormone estrogen to synthesize vitelogenin. Vitellogenin is a precursor of egg yolk contains cholesterol, protein and lipid. The cholesterol and fats for metabolism and the production of vitellogenin would cause changes in lipid metabolism that would affect blood lipid profile. Beta-carotene is a potent antioxidant, so it can be used in protecting omega-3 fatty acids (Hennekens et al., 1996). EPA and DHA were an example of an omega-3 fatty acids that could be found in Sardinella lemuru fish oil can lower blood cholesterol levels in fatty acid hydrolysis by-products.

Table 3 showed that feed without Indigofera zollingeriana leaf meal and Sardinella lemuru fish oil (IOL0) produced different meat cholesterol $(\mathrm{P}<0.05)$ from all other treatments; however, I5.5L0, I0L2 and I5.5L2 were not different. Meat cholesterol of laying duck in this research ranged from $0.11 \pm 0.01$ to $0.28 \pm 0.01 \mathrm{mg} / \mathrm{g}$. This is because beta carotene from Indigofera zollingeriana leaf meal function as antioxidant that prevent the forming of free radicals and increase oxidative stability of lipid which effects decrese of meat cholesterol. Antioxidant compounds derived from beta-carotene Indigofera zollingeriana leaf meal highly efficient in free radical prey to protect LDL from oxidation in vitro in the blood circulation (Karppi et al., 2010). LDL mass formed of cholesterol by $50 \%$. LDL protection of beta-carotene in preventing cell damage can increase the effectiveness of the use of Sardinella lemuru fish oil, that are lowering blood cholesterol levels. A decrease in blood cholesterol levels will affect the reduction in 
cholesterol levels in meat laying ducks aged 32 weeks.

\section{CONCLUSION}

Feeding Indigofera zollingeriana leaf meal $5.5 \%$ and Sardinella lemuru fish oil $2 \%$ in laying duck's diet could maintain the balance of blood lipid profiles by lowering plasma triglycerides, LDL, cholesterol and raising up plasma HDL and plays an important role on lipid metabolism of Magelang laying ducks to produce eggs and meat with low cholesterol content.

\section{ACKNOWLEDGMENTS}

The authors would like to thank Directorate General of Higher Education of Indonesia for supporting this research through BOPTN Funding Research Program 2015.

\section{REFERENCES}

Adkins, Y. and D.S. Kelley. 2010. Mechanisms underlying the cardioprotective effects of omega-3 polyunsaturated fatty acids. J. Nutr Biochem 21(9):781-792.

Asmariani, W.G and E. Probosari. 2012. Pengaruh pemberian buah pepaya (Carica papaya $L$.) terhadap kadar kolesterol LDL dan kolesterol HDL pada tikus Sprague Dawley dengan hiperkolesterolemia. J. Nutr. Coll. 1(1): 256-268.

Atakisi, E., O. Atakisi, H. Yaman and I. Arslan. 2009. Omega-3 fatty acid application reduces yolk and plasma cholesterol levels in Japanese quails. Food and Chem. Toxicol. 47: 2590-2593.

Avila-Ramos, F., A. Pro-Martinez, E. SosaMontes, C.M. Cuca-Garcia, C. Becerril Perez, J.L. Figueroa-Velasco, C.A. RuizFeria, A.S. Hernandez-Cazares and C. Narciso-Gaytan. 2013. Dietary supplemented and meat-added antioxidants effect on the lipid oxidative stability of refrigerated and frozen cooked chicken meat. Poult. Sci. 92 :243-249

Babio, N., R. Balanza, J. Basulto, M. Bulló and J. Salas-Salvadó. 2010. Dietary fibre: influence on body weight, glycemic control and plasma cholesterol profile. Nutr. Hosp. 25(3):327-340. Botsoglou, E., A. Govaris, D. Fletouris and N. Botsoglou. 2012. Lipid oxidation of stored eggs enriched with very long chain $n-3$ fatty acids, as affected by dietary olive leaves (Olea europea L.) or $\alpha$ tocopheryl acetate supplementation. Food Chem. 134(2):1059-1068.

Bruss, M.L. 2008. Lipids and Ketones. In: Clinical Biochemistry of Domestic Animals. $6^{\text {th }}$ Ed. Kaneko, J.J., Harvey, J.W., Bruss, M.L (Eds.). Academic Press Inc., New York, USA., pp: 81-116.

Burke, R.W., B.I. Diamondstone, R.A. Velapoldi and O. Menis. 1974. Mechanisms of the Liebermann-Burchard and Zak Color Reactions for Cholesterol. Clin. Chem. 20:94-801.

Carjavall-zarrabal, O., S.M. Waliszewski, D.M. Barradas-Dermitz, Z. Orta-Flores, P.M. Hayward-Jones, C. Nolasco-Hipólito, Angulo-Guerrero, R. Sánchez-Ricaňo, R.M. Infanzón and P.R. Trujillo. 2005. The consumption of hibiscus sabdariffa dried calyx ethanolic extract reduced lipid profile in rats. Plant Foods Hum. Nutr. 60:153-159.

Chan, D.C., G.F. Watts, T.A. Mori, P.H.R. Barrett, T.G. Redgrave and L.J. Beilin. 2003. Randomized controlled trial of the effect of n-3 fatty acid supplementation on the metabolism of apolipoprotein B-100 and chylomicron remnants in men with visceral obesity. American J. Clin. Nutr. 77: 300307.

Chang, H.S and W.C. Huang. 2001. Processing of poultry products in animal husbandry. Chinese Society of Anim. Sci. 435-542.

Dalle Zotte, A., P. Berzaghi, L.M. Jansson and I. Andrighetto. 2006. The use of near infrared reflectance spectroscopy (NIRS) in the prediction of chemical composition of freeze dried egg yolk and discrimination between different n-3 PUFA feeding sources. Anim. Feed Sci. Technol. 128:108121.

Darmawan, A., K.G. Wiryawan and Sumiati. 2013. Egg production and quality of magelang duck fed diets containing different ratio of omega- 3 : omega- 6 and organic Zn. Med. Pet. 36(3):197-202.

Hennekens, C.H., J.E. Buring, J.E. Manson, M. Stampfer, B. Rosner, N.R. 1996. Lack of effect of long-term supplementation with beta carotene on the incidence of malignant neoplasms and cardiovascular disease. $\mathrm{N}$. Engl J Med. 334(18):1145-1149. 
Karppi, J. T. Nurmi, S. Kurl, T.H. Rissanen and K. Nyyssonen. 2010. Lycopene, lutein and carotene as determinants of LDL conjugated dienes in plasma. Atherosclerosis. 209(2):565-572.

Komala, I. 2008. Kandungan Gizi Produk Peternakan. UGM Press, Yogyakarta.

Kong, B., H. Zhang and Y.L. Xiong. 2010. Antioxidant activity of spice extracts in a liposome system and in cooked pork patties and the possible mode of action. Meat Sci. 85:772-778.

Leeson, S. and J.D. Summers. 2005. Commercial Poultry Nutrition. Ed ke-3. Nottingham Univ. Pr. Nottingham.

McNamara, D.J. and H.S. Thesmar. 2005. Eggs. Egg Nutrition Center. Washington DC.

McNulty, H., R.F. Jacob, R.P. Mason. 2008. Biologic activity of carotenoids related to distinct membrane physicochemical interactions. Am. J. Cardiol. 22:20D-9D

Palupi, R., L. Abdullah, D.A. Astuti and Sumiati. 2014. Potensi dan pemanfaatan tepung pucuk Indigofera sp. sebagai bahan pakan substitusi bungkil kedelai dalam ransum ayam petelur. J. Ilmu Ternak dan Veteriner. 19(3): 210-219.

Ruan, D., Y.C. Lin, W. Chen, S. Wang, W.G. Xia, A.M. Fouad and C.T. Zheng. 2015. Effects of rice bran on performance, egg quality, oxidative status, yolk fatty acid composition, and fatty acid metabolismrelated gene expression in laying ducks. Poult. Sci. 94(12):2944-2951.

Schreiber, S.B., J.J. Bozell, D.G. Hayes and S. Zivanovic. 2013. Introduction of pri-mary antioxidant activity to chitosan for application as a multifunctional food packaging material. Food Hydrocolloids. 33(2):207-214.

Shahidi, F. and Y. Zhong. 2010. Lipid oxidation and improving the oxidative stability. Chem. Soc. Rev. 39:4067-4079.

Steel, R.G.D. and J.H. Torrie. 1984. Principles and Procedures of Statistics. McGraw-Hill Book Co. Inc. New York.

Surai, P.F., I.F. Vladimir and K. Filiz. 2016. Antioxidant systems in chick embryo development. Part 1. Vitamin E, carotenoids and selenium. Anim. Nutr. 2(1):1-11.

Trujillo, L.S., E.A. Decker and D.J. McClements. 2016. Influence of an anionic polysaccharide on the physical and bxidative stability of omega-3 nanoemulsions: Antioxidant effects of alginate. Food Hydrocolloids. 52:690.

Yang, X.J., J.Y. Zhuang, K.Q. Rao, X. Li and R.Q. Zhao. 2010. Effect of early feed restriction on hepatic lipid metabolism and expression of lipogenic genes in broiler chickens. Res. Vet. Sci. 89:438-444. 